\title{
Chemometric Evaluation of WWTPs' Wastewaters and Receiving Surface Waters in Bulgaria
}

\author{
Veronika Mihaylova $^{1}$, Galina Yotova ${ }^{1}$, Błażej Kudłak ${ }^{2} \mathbb{D}$, Tony Venelinov ${ }^{3} \mathbb{D}$ and Stefan Tsakovski ${ }^{1, *}$ \\ 1 Chair of Analytical Chemistry, Faculty of Chemistry and Pharmacy, Sofia University "St. Kliment Ohridski", \\ 1164 Sofia, Bulgaria; v.mihaylova@chem.uni-sofia.bg (V.M.); g.yotova@chem.uni-sofia.bg (G.Y.) \\ 2 Department of Analytical Chemistry, Faculty of Chemistry, Gdańsk University of Technology, \\ 11/12 Narutowicza, 80-233 Gdańsk, Poland; blakudla@pg.edu.pl \\ 3 Chair of Water Supply, Sewerage, Water and Wastewater Treatment, Faculty of Hydraulic Engineering, \\ University of Architecture, Civil Engineering and Geodesy, 1046 Sofia, Bulgaria; tvenelinov_fhe@uacg.bg \\ * Correspondence: stsakovski@chem.uni-sofia.bg; Tel.: +359-2-816-1426
}

Citation: Mihaylova, V.; Yotova, G.; Kudłak, B.; Venelinov, T.; Tsakovski, S. Chemometric Evaluation of WWTPs' Wastewaters and Receiving Surface Waters in Bulgaria. Water 2022, 14, 521. https://doi.org/ $10.3390 /$ w14040521

Academic Editors: Ana Rita Lado Ribeiro and Stefano Papirio

Received: 16 December 2021

Accepted: 7 February 2022

Published: 10 February 2022

Publisher's Note: MDPI stays neutral with regard to jurisdictional claims in published maps and institutional affiliations.

Copyright: (C) 2022 by the authors. Licensee MDPI, Basel, Switzerland. This article is an open access article distributed under the terms and conditions of the Creative Commons Attribution (CC BY) license (https:// creativecommons.org/licenses/by/ $4.0 /)$.

\begin{abstract}
Wastewater treatment plant (WWTP) installations are designed and operated to reduce the quantity of pollutants emitted to surface waters receiving treated wastewaters. In this work, we used classical instrumental studies (to determine chemicals and parameters under obligations put with Directive 91/271/EEC), ecotoxicological tools (Sinapis alba root growth inhibition (SA-RG) and Heterocypris incongruens mortality (MORT) and growth inhibition (GRINH)) and multivariate statistical analysis to gain information on feature profiles of WWTPs' effluents and the possible burden of surface water bodies receiving treated wastewaters in eleven locations of Bulgaria. Initial screening of results has shown that only phosphorus content exceeds the admissible level in 5 out 11 WWTP effluents, while $\mathrm{As}, \mathrm{Cr}, \mathrm{Cu}, \mathrm{Mn}$, and $\mathrm{Zn}$ show exceedance at several locations. The multivariate statistical analysis reveals the discriminating water quality parameters and outlines the ability of Heterocypris incongruens to evaluate the ecotoxicological potential of different groups of waters.
\end{abstract}

Keywords: wastewater treatment plant; surface water quality; ostracods; partial least squares-discriminant analysis

\section{Introduction}

Population growth (estimated at 10 billion by 2050 [1]) increasingly demands larger quantities of good quality water for diverse purposes-to ensure life, human health, and the prosperity of the economy. The sustainable development of aquatic ecosystems requires even higher volumes of wastewater to be treated and, subsequently, discharged into water bodies. However, as approximately $80 \%$ of used water is returned untreated [1], the deterioration of water quality has become a major problem worldwide. Reliable and accurate pollution assessment of water bodies, systematically, is important in the prediction of pollution (intentional or accidental), caused by the diversion of chemical and biochemical processes [2]. Therefore, there is a necessity for pollution control in a sound and cost-effective way to prevent the worsening of the chemical and ecological quality of the receiving waters [3]. Adopting the European Union (EU) legislation, Bulgarian national environmental bodies regularly assess the quality of surface waters and the efficiency of wastewater treatment processes.

The point and non-point (diffuse) source pollution control pursue the same goal-water quality protection and improvement. Stormwater runoff quality (diffuse source) should be viewed in the same manner as a point source of pollution, yet it is not as strictly controlled as wastewater effluent [4]. Most WWTPs in developed countries use different treatment facilities for wastewater treatment-primary sedimentation, biological treatment and tertiary chemical processes. Nevertheless, they are still perceived as a possible source of contamination to the surface water bodies [5] and their work is strictly regulated (mainly 
for threshold levels of total suspended solids (TSS), biochemical oxygen demand on the fifth day $\left(\mathrm{BOD}_{5}\right)$, chemical oxygen demand $(\mathrm{COD})$, total phosphorus $(\mathrm{TP})$ and total nitrogen (TN) [6].

Elevated concentrations of metals are also detectable in the raw water entering the WWTP [7]. Metals enter river systems via surface runoff (diffuse sources) [8], but also through industrial or municipal wastewaters, discharged directly or conveyed towards WWTPs where, after treatment, they are released into the surface water bodies. To date, the prevention of surface water deterioration has been accomplished by regulatory mechanisms for monitoring municipal and industrial effluents [9]. Although most metals are retained by the WWTPs during the treatment process, their discharged loads into the receiving rivers are not negligible [10]. A calculation of the total metal loads from these point sources is performed by runoff coefficients and enrichment ratios in soils [11] and using the metal concentration multiplied by the flow rate [12].

In addition, statistical methods such as principal component analysis (PCA) are often used in the assessment of pressures and impacts from identified sources [13-15] and showed the apportionment of the WWTP effluents [16]. Supplementary to the studies of physical-chemical parameters, major and trace elements, utilization of ecotoxicological indicators was introduced to comprehensively assess the WWTPs' efficiencies and water quality of the effluents discharged into the surface waters' quality [14,17]. As emphasized by the U.S. Environmental Protection Agency [18], physicochemical analyses, in most cases, provide limited information on water quality and should be performed synergistically with ecotoxicological investigations. In this respect, it was demonstrated that ecotoxicological indicators could successfully be implemented to access the quality of the WWTP treatment operations. They embody the possibility to determine simultaneously the holistic impact and the pollution effect to the environment [19]. Ostracodtoxkit F $^{\mathrm{TM}}$ has had only limited application to water quality assessments [20] and WWTPs [21,22], contrary to soils [23-28], sediments [29-31] and sewage sludge [32,33].

The present study aims to assess the specific feature profiles of Bulgarian WWTPs wastewaters and receiving surface waters, with special emphasis on (i) improvement of the sampling strategy by collecting samples from WWTP influents and effluents on one hand, and from the water bodies before and after effluent discharge on the other; (ii) monitoring a representative set of physicochemical water quality parameters [chlorides $\left(\mathrm{Cl}^{-}\right)$, chemical oxygen demand (COD), electroconductivity (EC), nitrates $\left(\mathrm{NO}_{3}{ }^{-}\right)$, total phosphorus (TP), $\mathrm{pH}$, sulphates $\left(\mathrm{SO}_{4}{ }^{2-}\right)$, total nitrogen (TN), total organic carbon (TOC), total hardness (TH), total suspended solids (TSS)], major components ( $\mathrm{Ca}, \mathrm{K}, \mathrm{Mg}$ and $\mathrm{Na}$ ) and trace elements (Al, As, Ba, Cd, Co, Cr, Cu, Fe, Mn, Ni, Pb, Se, $\mathrm{U}_{\text {nat, }} \mathrm{V}$ and $\mathrm{Zn}$ ), and the application of Phytotoxkit $\mathrm{F}^{\mathrm{TM}}$ and Ostracodtoxkit $\mathrm{F}^{\mathrm{TM}}$ in the sub-chronic toxicity assessment; (iii) revealing the latent factors controlling water quality and showing the difference in the water quality parameters at the inlet and the outlet of the WWTPs, and rivers receiving their discharged loads by multivariate statistical analysis. To the best of our knowledge, the proposed methodology, including the proposed monitoring scheme and multivariate statistical modelling, for evaluation of WWTPs' wastewaters and receiving surface waters is undertaken for the first time in this study.

\section{Materials and Methods}

\subsection{Sampling and Sample Preparation}

Forty-four water samples (11 at the WWTPs' inlets, 11 at the WWTPs' outlets and 22 surface waters-before and after the discharge point of respective WWTP) were collected in August 2020 (Figure 1) according to the sampling strategy (Figure 2). 

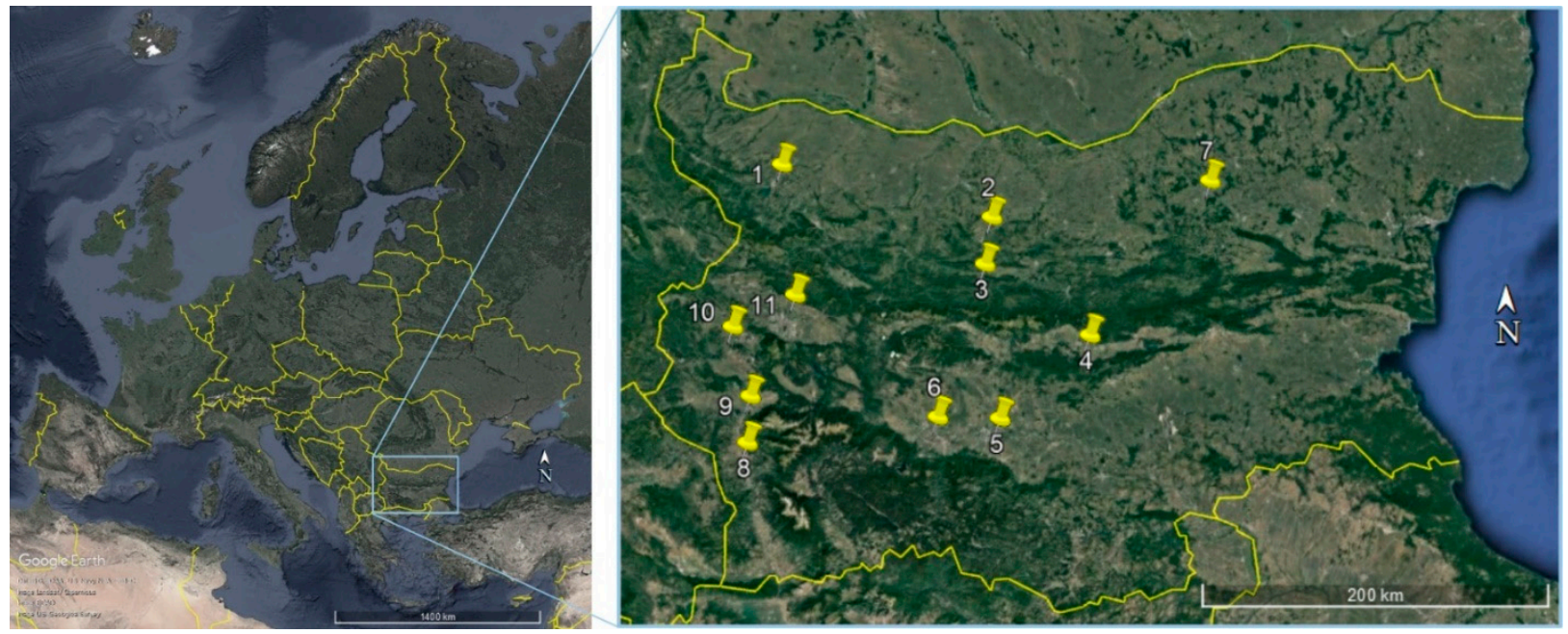

Figure 1. Sampling locations of the WWTPs.

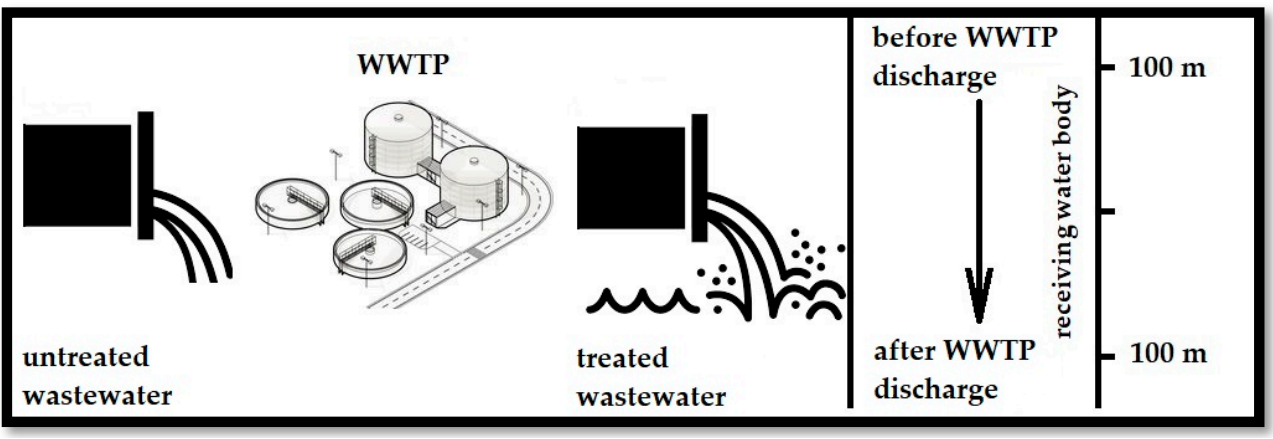

Figure 2. General representation of the sampling scheme at each sampling location.

After collection, water samples were stored at $4{ }^{\circ} \mathrm{C}$ in dark glass bottles before transportation to a laboratory. For ICP-MS analysis, fifty millilitres of water were filtered with a $25 \mathrm{~mm}$ PES sterile syringe filter $(0.45 \mu \mathrm{m})$ and acidified with $0.05 \mathrm{~mL}$ of concentrated nitric acid. For ecotoxicological analysis, two hundred and fifty millilitres of water were filtered with a $25 \mathrm{~mm}$ PES sterile syringe filter $(0.2 \mu \mathrm{m})$ and frozen.

\subsection{Physicochemical Analysis}

Sample preparation and measurement conditions are described by the producer of the cuvette tests and already presented [14]. Different cuvette tests were used for the determination of COD-LCK 114 for the inlet samples and LCK 1414 for outlet and surface waters. LCK 138, 339, 348 and 311 were used for the determination of TN, nitrates, TP and $\mathrm{Cl}^{-}$, respectively. For the determination of TOC-LCK 381 for the inlet samples and LCK 380 for outlet and surface waters was used. Spectrophotometer DR 3900 (Hach Lange $\mathrm{GmbH}$, Berlin, Germany) was used for all determinations.

Barium chloride in the form of a powder reagent (SulfaVer 4) was used for the determination of $\mathrm{SO}_{4}{ }^{2-}$ in all the water samples.

SensIon+ MM734 (Hach Lange GmbH, Berlin, Germany) was used for the determination of $\mathrm{pH}$ and EC.

The determination of the TH and TSS strictly followed the requirements of ISO 6059:1984 and EN 872:2006, respectively.

\subsection{ICP-MS Method of Analysis}

The surface water samples were measured by Perkin-Elmer SCIEX Elan DRC-e ICPMS (MDS Inc., Concord, Ontario, Canada). The mass spectrometer was optimized to obtain minimal values of spectral interferences and maximum intensity of the analytes' signals. 
The chemical concentration of 19 elements (Al, As, Ba, Ca, Cd, Co, Cr, Cu, Fe, K, Mg, $\mathrm{Mn}, \mathrm{Na}, \mathrm{Ni}, \mathrm{Pb}, \mathrm{Se}, \mathrm{U}_{\text {nat }}, \mathrm{V}$ and $\mathrm{Zn}$ ) were measured, using a Dynamic Bandpass Tuning parameter- $\mathrm{RPa}$ for the major elements, as described in [34]. The concentrations of As and Se were analysed in a DRC mode [35] for the elimination of Ar-based polyatomic interferences. The oxygen flow rate and the Dynamic Bandpass Tuning parameter $(\mathrm{RPq})$ are shown after the respective isotopes in brackets (Table 1).

Table 1. Instrumental conditions for ICP-MS measurement (Perkin-Elmer SCIEX DRC-e).

\begin{tabular}{|c|c|}
\hline Instrument & Operating Conditions \\
\hline Argon plasma gas flow & $15 \mathrm{~L} / \mathrm{min}$ \\
\hline Auxiliary gas flow & $1.20 \mathrm{~L} / \mathrm{min}$ \\
\hline Nebulizer gas flow & $0.90 \mathrm{~L} / \mathrm{min}$ \\
\hline Lens voltage & $6.00 \mathrm{~V}$ \\
\hline ICP-RF power & $1100 \mathrm{~W}$ \\
\hline Pulse stage voltage & $950 \mathrm{~V}$ \\
\hline Dwell time & $50 \mathrm{~ms}$ \\
\hline Acquisition mode & Peak hop \\
\hline Peak pattern & One point per mass at maximum peak \\
\hline Number of runs & 4 \\
\hline Determined isotopes of trace elements & $\begin{array}{c}{ }^{27} \mathrm{Al},{ }^{51} \mathrm{~V},{ }^{52} \mathrm{Cr},{ }^{54,}{ }^{57} \mathrm{Fe},{ }^{59} \mathrm{Co},{ }^{55} \mathrm{Mn},{ }^{60,62} \mathrm{Ni}, \\
63,65 \mathrm{Cu},{ }^{64,66,68} \mathrm{Zn},{ }^{75} \mathrm{As}(1.0 / 0.7) *{ }^{77,78} \mathrm{Se} \\
(1.5 / 0.3){ }^{*}{ }^{80,82} \mathrm{Se}(0.9 / 0.3){ }^{*}{ }^{\prime} 113,{ }^{114} \mathrm{Cd} \\
137,138 \mathrm{Ba},{ }^{206,}{ }^{208} \mathrm{~Pb},{ }^{238} \mathrm{U}\end{array}$ \\
\hline
\end{tabular}

Single element standard solutions of all measured chemical elements (Fluka, Steinheim, Switzerland) with an initial concentration of $1000 \mathrm{mg} / \mathrm{L}$ were used to construct the calibration curves after adequate dilution. The calibration concentration range was from 0.2 to $10 \mathrm{mg} / \mathrm{L}$ for major components and from 0.01 to $100 \mu \mathrm{g} / \mathrm{L}$ for trace elements. All standard solutions were diluted with double deionized water (Millipore purification system Synergy, Molstheim, France). The coefficients of determination for obtained calibration curves were at least 0.99 . For the acidification of the water samples, ultrapure nitric acid (67-69\% $\mathrm{HNO}_{3}$, Fisher Chemicals, Waltham, MA, USA, Trace Metal Grade) was used. The instrumental conditions for ICP-MS are presented in Table 1.

The accuracy of the method was confirmed by analysis of three surface water certified reference materials-NIST1640a (Trace Elements in Natural Water, National Institute of Standards and Technology, Gaithersburg, Maryland, USA), SPS-SW2 (Reference Material for Measurement of Elements in Surface Waters, Spectrapure Standards, Tempe, Norway) and NWTM-23.5 (Environmental matrix reference material, a trace element-fortified sample, Environment and Climate Change, Gatineau, QC, Canada). The obtained experimental results were in excellent agreement with the certified values. The recoveries for each element concentration (from $98.5 \%$ to $102.6 \%$ and from $99.7 \%$ to $100.3 \%$ for major components and trace elements, respectively) were calculated based on the obtained results and the certified values. To assess the precision of the analysis, which is in the interval 1-9\%, all samples were analysed in triplicate. The concentrations of the major components $(\mathrm{Ca}, \mathrm{K}$, $\mathrm{Mg}$ and $\mathrm{Na}$ ) were not included in the dataset used for multivariate statistical analysis.

\subsection{Ostracodtoxkit $F^{\mathrm{TM}}$}

Ostracodtoxkit FTM (MicroBioTests Inc., Gent, Belgium) was used for the determination of sub-chronic toxicity by a direct contact modified procedure using the Heterocypris incongruens crustaceans. These organisms are used successfully in environmental monitoring due to their high sensitivity to the organic contaminants and heavy metals present in the seas and fresh-water bodies. The toxicity is determined by two effects: growth inhibition (GRINH) and the mortality (MORT) of organisms as a result of contact with harmful ingredients present in the sample [36]. Hatched Heterocypris incongruens cysts were placed 
in a Petri dish $\left(48 \mathrm{~h}, 25^{\circ} \mathrm{C}\right.$, continuous illumination of 3000-4000 lux) and pre-fed with Spirulina powder for $4 \mathrm{~h}$ of freshly hatched organisms after $48 \mathrm{~h}$. Fifteen freshly hatched organisms were immobilized with Lugol fixate and their length was measured to serve as the initial length value $\left(\mathrm{L}_{0}\right)$. Six-welled plates were filled with $1 \mathrm{~cm}^{3}$ of standard reference sediment (RSED050613, MicroBioTests Inc., Gent, Belgium) and $2 \mathrm{~cm}^{3}$ of standardized algal food prepared with Selenastratum capricornatum to ensure feeding of ostracods for the entire test run period. Then, $2 \mathrm{~cm}^{3}$ of sample water was added to the respective wells in plates (each experiment was repeated three times) and ten ostracods were transferred from the Petri dish to the given test well. Plates were sealed with Parafilm, and the contact tests were run for six days (room temperature, darkness). Afterwards, living organisms were caught from all plates, counted, immobilized with Lugol fixate and their length was measured (a similar procedure has been performed for the control plate with distilled water used as a reference sample). These data were used to calculate the GRINIH, and MORT of samples studied according to the following formulae:

$$
\text { GRINH }=\left[100-\left(\frac{L_{\text {test.end }}-L_{0}}{L_{\text {control.end }}-L_{0}}\right)\right] \cdot 100 \%
$$

where:

$L_{\text {test }} \cdot$ end - mean length of organisms exposed to the tested sample $[\mu \mathrm{m}]$,

$L_{\text {control-end }}$-mean length of organisms exposed to the control sample $[\mu \mathrm{m}]$,

$L_{0}-$ mean length of organisms at the beginning of the experiment $[\mu \mathrm{m}]$,

and

$$
\text { MORT }=\left[100-\frac{N_{\text {test }}}{N_{\text {control }}}\right] \cdot 100 \%
$$

where:

$N_{\text {test }}$-number of living organisms exposed to the tested sample after the experiment, $N_{\text {control }}$-number of living organisms in the control after the experiment.

The test is considered to be run satisfactory if the mortality of organisms in the control samples is lower than $20 \%$ and the mean growth increment of organisms in the control sample is greater than $400 \mu \mathrm{m}$ (both of these conditions were always valid in all experiments).

\subsection{Phytotoxkit F ${ }^{\mathrm{TM}}$}

The Phytotoxkit FTM (MicroBioTests Inc., Gent, Belgium) microbiotest is a simple and practical phytotoxicity test that allows direct measurement of the length of roots in special transparent test plates using image analysis. Phytotoxkit $\mathrm{F}^{\mathrm{TM}}$ is originally applied for soil samples ecotoxicity determination but Wieczerzak et al. [37] applied it to modelling and real liquid samples. Presently, MicroBioTests Inc. designed Phytotestkit for liquid samples as a variant of the Phytotoxkit $\mathrm{F}^{\mathrm{TM}}$ assay.

After $72 \mathrm{~h}$ of exposure, the change in seed germination and the root growth of Sorghum saccharatum, Lepidium satioum and Sinapis alba is used by the Phytotoxkit FTM in the ecotoxicity assessment. In a previous study [14], it was found out that the root growth of Sinapis alba was the most significant and sensitive indicator (out of the eight analysed ecotoxicological indicators) to distinguish between the Bulgarian WWTP effluents from the receiving surface waters. In the present study, the procedure proposed by Wieczerzak et al. [37] was followed and the root growth of Sinapis alba (SA-RG) was used as an indicator for the phytotoxicity of the samples. A layer of $100 \%$ pure cotton wool $(6.0 \pm 0.2 \mathrm{~g}$, placed in a plastic test plate) was soaked with $18 \mathrm{~mL}$ of the studied water sample. The soaked wool was covered with black filter paper and ten seeds of the test plant were placed in the test area. The control sample was prepared in the same way using distilled water. The images of test plates were taken after $72 \mathrm{~h}$ of incubation in darkness at $25^{\circ} \mathrm{C}$ and the root growth was measured using 
Image J (NIH, Bethesda, MD, USA) [38]. The percentage inhibition of root growth was subsequently calculated as follows:

$$
\text { Effect }(\%)=(\mathrm{A}-\mathrm{B}) / \mathrm{A} \times 100
$$

where:

A-mean root length in the control sample [mm],

B-mean root length in the tested sample [mm].

The validity of the performed biotest was checked with two criteria: the mean germination success in the control test plates must be at least $70 \%$ and the mean root length in the control test plates must be at least $30 \mathrm{~mm}$. Both conditions were passed in all experiments carried out.

\subsection{Multivariate Statistical Analysis}

In this study principal component analysis (PCA) and partial least squares-discriminant analysis (PLS-DA) were applied to explore the experimental results.

Multivariate analysis and visualization of surface waters monitoring datasets are achieved through the application of PCA $[39,40]$. The principal components (latent factors) describe the major variance sources and presents data structure to a great extent. The extraction of principal components (PCs) is performed by decomposition of the input data matrix as a product of two orthogonal factor matrices: factor loadings and factor scores. Factor loadings present the weights of original variables in the formation of new variables (factors or PCs) and give information about principal component origin. Factor scores present the projections of the original data on PCs and could be used for the identification of similarity groups between investigated samples.

PLS-DA is a not so widely used pattern recognition technique in environmental assessment studies [14]. PLS-DA is a special form of partial least square modelling combining PLS components construction followed by discriminant analysis in the space of extracted PLS components. In this study, discrimination of different classes of samples (treated, untreated wastewaters, surface waters) is performed by PLS1 algorithm, which is used to model the relationships between independent block of variables (water quality indicators) and dependent categorical dummy variable representing class membership of each sample. The output of the PLS-DA are several statistics concerning independent variables (physicochemical variables and ecotoxicological endpoints) and model performance. The variable importance on projection (VIP) is a measure of the importance of independent variables in the prediction model. If VIP $>1$ the variables have significant discriminative power in the classification model. The obtained regression vectors represent the variable profile of known sample classes. The area under the curve (AUC) is the main parameter assessing the performance of the prediction models. AUC $=1$ means perfect model prediction, while bad classification model is achieved for AUC $\leq 0.5$.

Before the PCA and PLS-DA analysis, the input data were auto-scaled and venetian blinds as cross-validation procedure was applied. All multivariate statistics models were performed in MATLAB R2021a using PLS Toolbox 9.0 (Eigenvector Research Inc., Manson, WA, USA).

\section{Results}

\subsection{Basic Statistics and Comparison with Environmental Quality Guidelines}

The basic statistics of water quality parameters at the inlets and the outlets of the WWTPs, and surface waters are shown in Table 2. 
Table 2. Basic statistics of water quality parameters $(n=44)$.

\begin{tabular}{|c|c|c|c|c|c|c|}
\hline & Units & Mean & Median & Minimum & Maximum & Std. Dev. \\
\hline $\mathrm{pH}$ & - & 7.7 & 7.6 & 6.9 & 8.9 & 0.4 \\
\hline $\mathrm{EC}$ & $\mathrm{mS} / \mathrm{cm}$ & 0.6 & 0.6 & 0.2 & 1.3 & 0.3 \\
\hline COD & $\mathrm{mg} / \mathrm{L} \mathrm{O}_{2}$ & 68.7 & 15.7 & 8.4 & 449.0 & 114.6 \\
\hline TOC & $\mathrm{mg} \mathrm{C} / \mathrm{L}$ & 10.7 & 9.6 & 1.0 & 42.9 & 9.5 \\
\hline $\mathrm{NO}_{3}{ }^{-}$ & $\mathrm{mg} / \mathrm{L}$ & 13.3 & 5.9 & 0.5 & 68.9 & 15.7 \\
\hline TN & $\mathrm{mg} / \mathrm{L}$ & 8.8 & 5.1 & 0.5 & 48.8 & 10.9 \\
\hline TSS & $\mathrm{mg} / \mathrm{L}$ & 35.3 & 8.5 & 1.5 & 611.0 & 96.9 \\
\hline $\mathrm{TP}$ & $\mathrm{mg} / \mathrm{L}$ & 3.1 & 2.4 & 0.3 & 12.0 & 3.0 \\
\hline $\mathrm{Cl}^{-}$ & $\mathrm{mg} / \mathrm{L}$ & 71.3 & 40.0 & 0.5 & 476.0 & 103.9 \\
\hline $\mathrm{SO}_{4}^{2-}$ & $\mathrm{mg} / \mathrm{L}$ & 41.5 & 33.0 & 3.0 & 148.0 & 27.5 \\
\hline $\mathrm{TH}$ & meq/L & 4.4 & 3.8 & 1.6 & 10.6 & 2.2 \\
\hline $\mathrm{Al}$ & $\mu \mathrm{g} / \mathrm{L}$ & 13.1 & 10.2 & 2.4 & 41.9 & 10.2 \\
\hline $\mathrm{V}$ & $\mu \mathrm{g} / \mathrm{L}$ & 1.8 & 1.4 & 0.4 & 6.0 & 1.3 \\
\hline $\mathrm{Cr}$ & $\mu \mathrm{g} / \mathrm{L}$ & 5.3 & 4.2 & 0.2 & 13.9 & 3.1 \\
\hline $\mathrm{Mn}$ & $\mu \mathrm{g} / \mathrm{L}$ & 53.4 & 40.0 & 5.1 & 262.6 & 45.4 \\
\hline $\mathrm{Fe}$ & $\mu \mathrm{g} / \mathrm{L}$ & 47.9 & 33.5 & 1.2 & 163.8 & 45.0 \\
\hline $\mathrm{Co}$ & $\mu \mathrm{g} / \mathrm{L}$ & 0.6 & 0.4 & 0.2 & 7.2 & 1.0 \\
\hline $\mathrm{Ni}$ & $\mu \mathrm{g} / \mathrm{L}$ & 3.9 & 3.4 & 1.4 & 13.2 & 2.1 \\
\hline $\mathrm{Cu}$ & $\mu \mathrm{g} / \mathrm{L}$ & 1.9 & 1.6 & 0.8 & 9.0 & 1.3 \\
\hline $\mathrm{Zn}$ & $\mu \mathrm{g} / \mathrm{L}$ & 11.4 & 5.4 & 0.07 & 102.7 & 17.3 \\
\hline As & $\mu \mathrm{g} / \mathrm{L}$ & 4.4 & 1.5 & 0.5 & 46.9 & 10.1 \\
\hline Se & $\mu \mathrm{g} / \mathrm{L}$ & 1.0 & 1.0 & 0.01 & 2.6 & 0.5 \\
\hline $\mathrm{Cd}$ & $\mu \mathrm{g} / \mathrm{L}$ & 0.02 & 0.01 & 0.0001 & 0.1 & 0.02 \\
\hline $\mathrm{Ba}$ & $\mu \mathrm{g} / \mathrm{L}$ & 31.2 & 28.3 & 12.2 & 64.5 & 12.2 \\
\hline $\mathrm{Pb}$ & $\mu \mathrm{g} / \mathrm{L}$ & 0.9 & 0.2 & 0.02 & 24.7 & 3.8 \\
\hline $\mathrm{U}_{\text {nat }}$ & $\mu \mathrm{g} / \mathrm{L}$ & 2.6 & 1.5 & 0.1 & 14.3 & 3.7 \\
\hline MORT & $\%$ & 15.6 & 8.9 & -3.6 & 67.9 & 18.9 \\
\hline GRINH & $\%$ & 26.9 & 25.0 & -4.7 & 84.2 & 15.6 \\
\hline SA-RG & $\%$ & -38.0 & -40.4 & -58.5 & -3.2 & 11.1 \\
\hline
\end{tabular}

No exceedances of the requirements of Directive 91/271/EEC [6] for all the discharges COD, TSS and TN were observed. For TP, exceedances above the concentration limits set in the Directive were observed at the outlets for 7 out of the 11 WWTPs studied (Table 3). Exceedances for the PDV, PAZ, DUP and PER were previously reported [16].

Table 3. Studied WWTPs, population equivalents, treatment facilities and exceedances.

\begin{tabular}{|c|c|c|c|c|c|c|c|}
\hline \multirow{2}{*}{ Number } & \multirow{2}{*}{$\begin{array}{l}\text { Sampling } \\
\text { Location }\end{array}$} & \multirow{2}{*}{$\begin{array}{c}\text { Population } \\
\text { Equivalent (p.e.) }\end{array}$} & \multirow{2}{*}{$\begin{array}{l}\text { Treatment } \\
\text { Facilities } 1\end{array}$} & \multicolumn{4}{|c|}{ Exceeding of the Directive 91/271/EEC ${ }^{2}$} \\
\hline & & & & COD & $\mathbf{T N}$ & TP & TSS \\
\hline 1 & Montana (MON) & 98,618 & 4 & - & - & - & - \\
\hline 2 & Lovech (LOV) & 85,700 & 4 & - & - & - & - \\
\hline 3 & Troyan (TRO) & 80,000 & 4 & - & - & - & - \\
\hline 4 & Kazanlak (KZK) & 80,000 & 4 & - & - & - & - \\
\hline 5 & Plovdiv (PDV) & 596,000 & 2 & - & - & + & - \\
\hline 6 & Pazardzhik (PAZ) & 150,000 & 2 & - & - & + & - \\
\hline 7 & Popovo (POP) & 37,720 & 3 & - & - & + & - \\
\hline 8 & Blagoevgrad (BLG) & 87,520 & 4 & - & - & + & - \\
\hline 9 & Dupnitsa (DUP) & 55,000 & 2 & - & - & + & - \\
\hline 10 & Pernik (PER) & 160,000 & 2 & - & - & + & - \\
\hline 11 & Sofia (SOF) & $1,833,333$ & 4 & - & - & + & - \\
\hline
\end{tabular}

${ }^{1}$ Treatment facilities are designated as follows: 1 -mechanical treatment; 2 -mechanical and biological treatment; 3-mechanical, biological treatment and nitrogen removal facility; 4-mechanical, biological treatment, nitrogen removal facility and chemical precipitation of phosphorus. ${ }^{2}$ The concentration limits $(\mathrm{mg} / \mathrm{L})$ according to Directive $91 / 271 /$ EEC are as follows: COD $(125 \mathrm{mg} / \mathrm{L})$; TN $(10 \mathrm{mg} / \mathrm{L}$ for more than 100,000 p.e., $15 \mathrm{mg} / \mathrm{L}$ for 10,000-100,000 p.e.); TP (1 mg/L for more than 100,000 p.e., $2 \mathrm{mg} / \mathrm{L}$ for 10,000-100,000 p.e.); TSS (35 mg/L for more than 10,000 p.e., $60 \mathrm{mg} / \mathrm{L}$ for $2000-10,000$ p.e.). 
Exceeding the set legal standards for surface waters was observed in the receiving water bodies for $\mathrm{Cr}$ before the discharge points of LOV and KZK, and before and after the discharge of POP. For Mn, exceedances were observed before the discharge of BLG, before and after the discharge points of KZK, POP, PER and SOF. Copper exceedances were observed before the discharge points of MON and LOV, as well as before and after the discharge points of TRO, PDV, PAZ, POP, PER and SOF. Zinc exceedances were only found after the discharge points of LOV and PDV, indicating that the WWTPs may adversely increase the $\mathrm{Zn}$ concentration in the receiving rivers. Exceedances of As were only found before and after the discharge of MON. No exceedances for $\mathrm{Al}, \mathrm{Fe}$ and $\mathrm{U}_{\text {nat }}$ were determined.

\subsection{PCA Results}

The performed PCA extracts four latent factors (PC1-PC4) which explain nearly 55\% of the total variance. The plots of the factor loadings for each PC are presented in Figure 3.
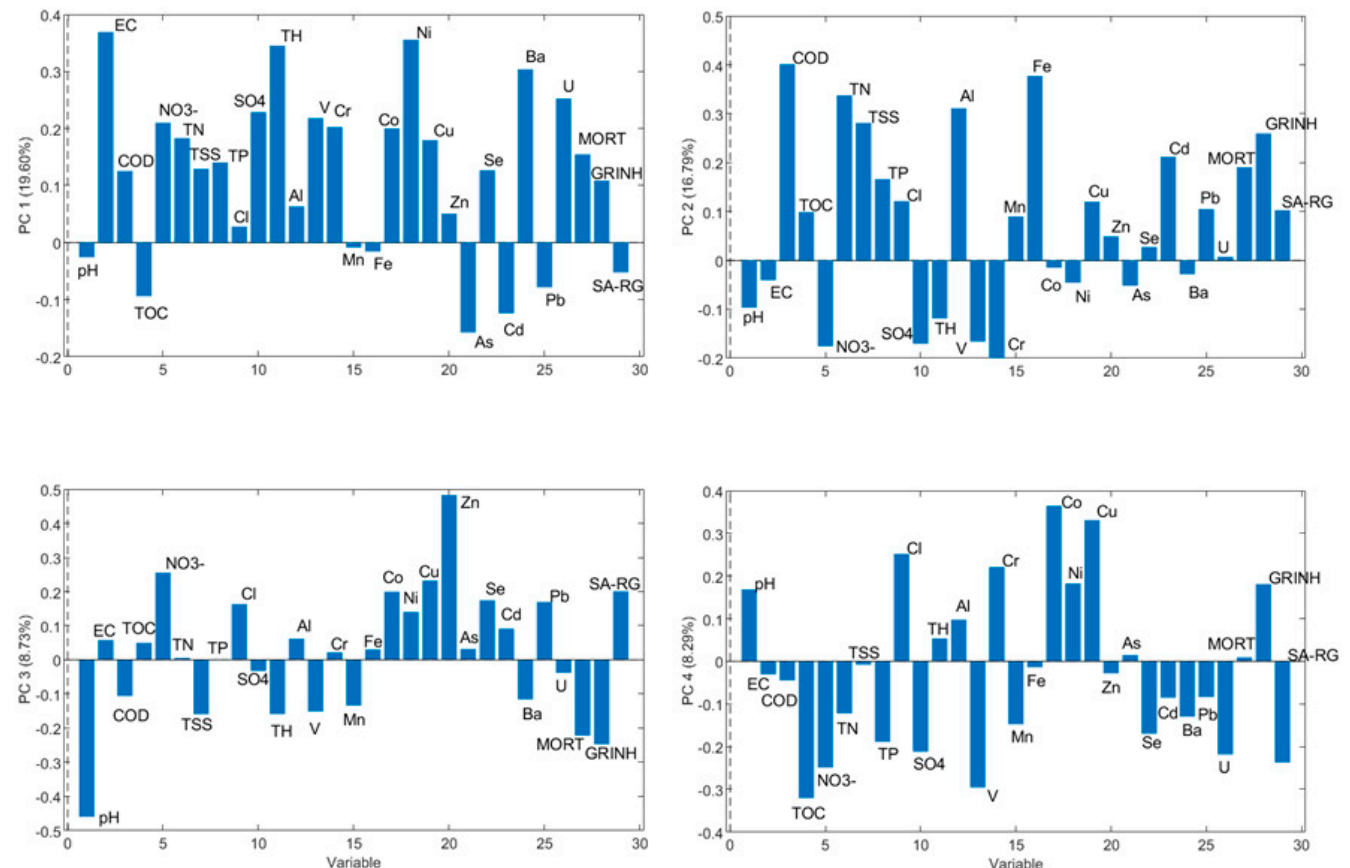

Figure 3. Factor loadings plot for four latent factors.

The first latent factor (PC1) explains almost $20 \%$ of the total variance and indicates a positive correlation of Heterocypris incongruens response points (MORT, GRINH) with EC, $\mathrm{TH}$ and some heavy metals. The second latent factor (explaining $17 \%$ of the total variance) reveals a strong correlation of all ecotoxicological endpoints with COD, nutrients (TN, TP), TSS, Al, Fe and Cd. The third latent factor (explaining 9\% of the total variance) represents the dissimilar behaviour between Heterocypris incongruens response points and Sinapis alba root growth inhibition (SA-RG). SA-RG is positively correlated with nitrates and some heavy metals (with $\mathrm{Zn}$ as the main representative), while MORT and GRINH are strongly correlated with $\mathrm{pH}$. The fourth latent factor (explaining $8 \%$ of the total variance) indicates a strong correlation of GRINH with $\mathrm{pH}$, chlorides and some heavy metals such as $\mathrm{Cr}, \mathrm{Co}$, $\mathrm{Ni}$ and $\mathrm{Cu}$.

The PC1 and PC2 factor scores of the investigated samples are presented in Figure 4. There is a clear indication that PC2 scores separate untreated wastewaters from the groups of treated wastewaters and surface waters (taken before and after WWTP discharge points). This separation could be attributed to the variables with a significant impact on the formation of PC2. 


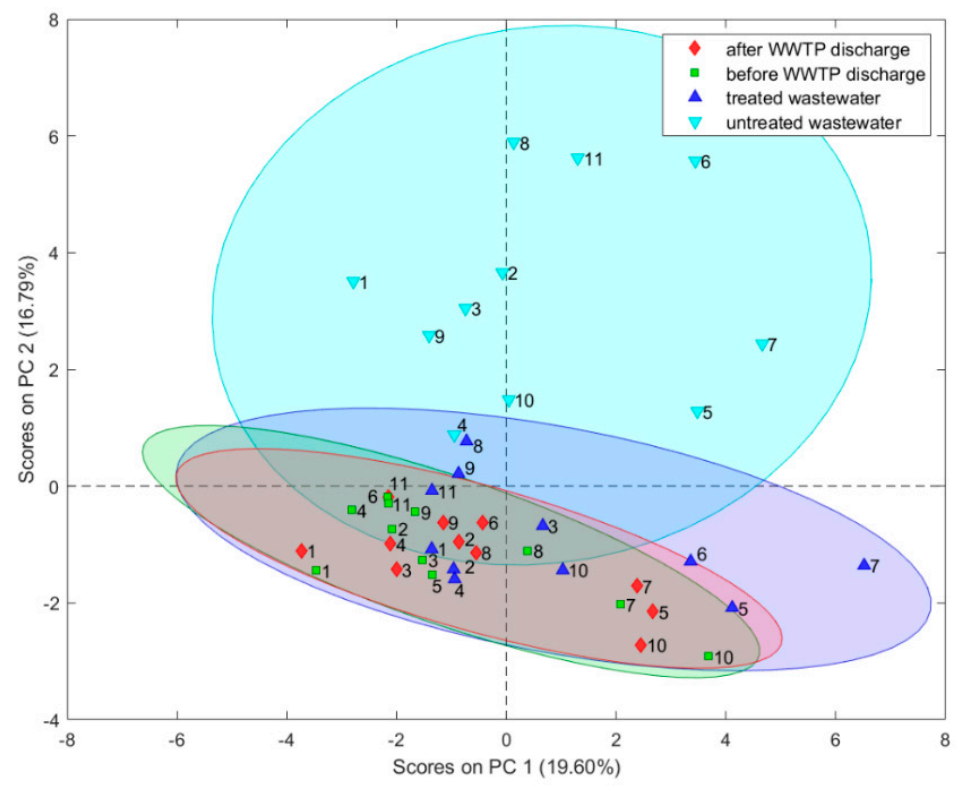

Figure 4. PC1 vs. PC2 factor scores plot.

Figure 5 represents the grouping of samples according to PC1 and PC3 factor scores. There is an observable moderate separation between treated wastewaters and the other groups based on PC3 scores that justifies an attempt undertaken to perform a more detailed investigation of variables responsible for the abovementioned grouping of samples, as presented below in the partial least squares-discriminant analysis (PLS-DA) section.

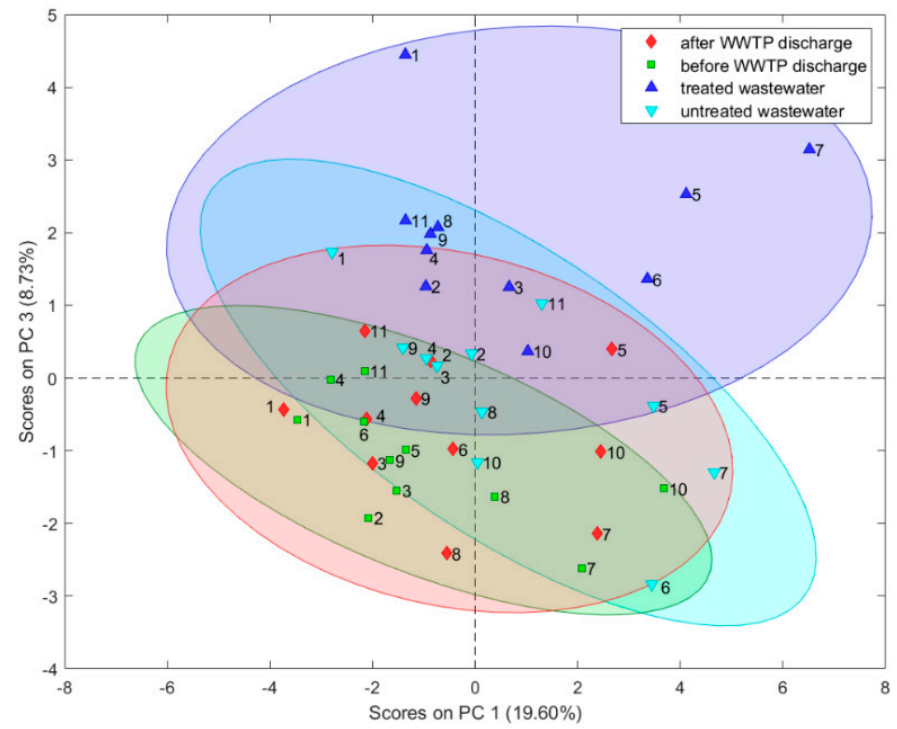

Figure 5. PC1 vs. PC3 factor scores plot.

\subsection{PLS-DA Results}

The first of the PLS-DA classification models includes all physicochemical parameters and ecotoxicological endpoints to discriminate the samples assigned to two classes: untreated wastewaters (11 samples) and treated wastewaters (11 samples). The confusion matrix and AUC values (calibration and cross-validated ones) resemble excellent model performance (ref. to Figure 6a). According to the variable importance on projection (VIP) score values (higher than 1), the following variables have the most significant contribution to the classification model: $\mathrm{pH}, \mathrm{COD}$, nitrates, TN, TSS, $\mathrm{Al}, \mathrm{Cr}, \mathrm{Fe}, \mathrm{Cd}$, MORT and GRINH (Figure $6 \mathrm{~b}$ ). The presented regression vectors, where only significant variables are marked, for untreated wastewaters (Figure 6c) and treated wastewaters (Figure 6d) resemble the 
concentration profiles of both classes. The untreated wastewaters are characterized with a higher $\mathrm{pH}, \mathrm{COD}, \mathrm{TN}, \mathrm{TSS}, \mathrm{Al}, \mathrm{Fe}, \mathrm{Cd}, \mathrm{MORT}$ and GRINH, while the treated wastewaters possess higher levels of nitrates and $\mathrm{Cr}$.

\begin{tabular}{|c|c|c|c|}
\hline $\begin{array}{l}\text { Confusion } \\
\text { matrix }\end{array}$ & $\begin{array}{l}\operatorname{AUC}(C)=1.000 ; \\
\operatorname{AUC}(C V)=0.950\end{array}$ & & \\
\hline & & \multicolumn{2}{|c|}{ Actual } \\
\hline & & $\begin{array}{c}\text { Untreated } \\
\text { wastewaters }\end{array}$ & $\begin{array}{c}\text { Treated } \\
\text { wastewaters }\end{array}$ \\
\hline \multirow{2}{*}{ Predicted } & $\begin{array}{c}\text { Untreated } \\
\text { wastewaters }\end{array}$ & 11 & 0 \\
\hline & $\begin{array}{c}\text { Treated } \\
\text { wastewaters }\end{array}$ & 0 & 11 \\
\hline
\end{tabular}

(a)

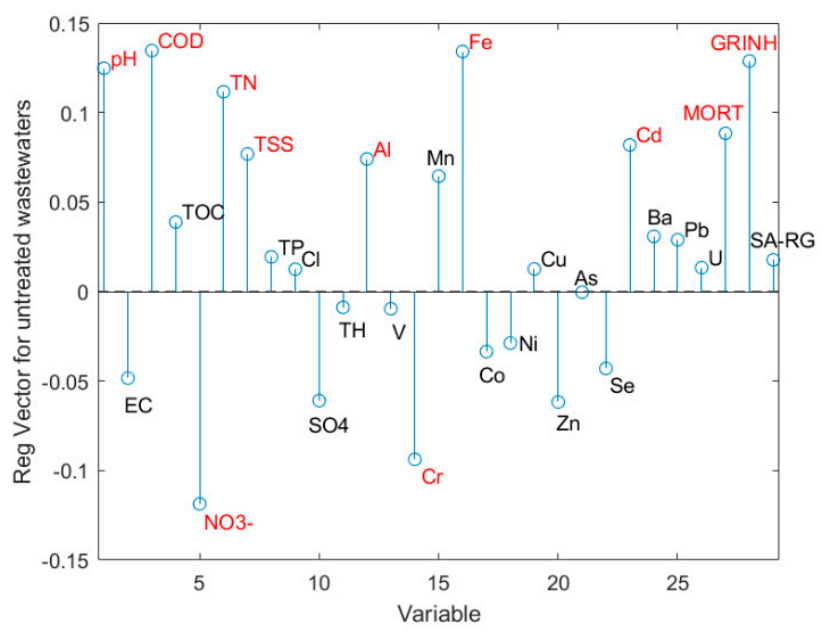

(c)

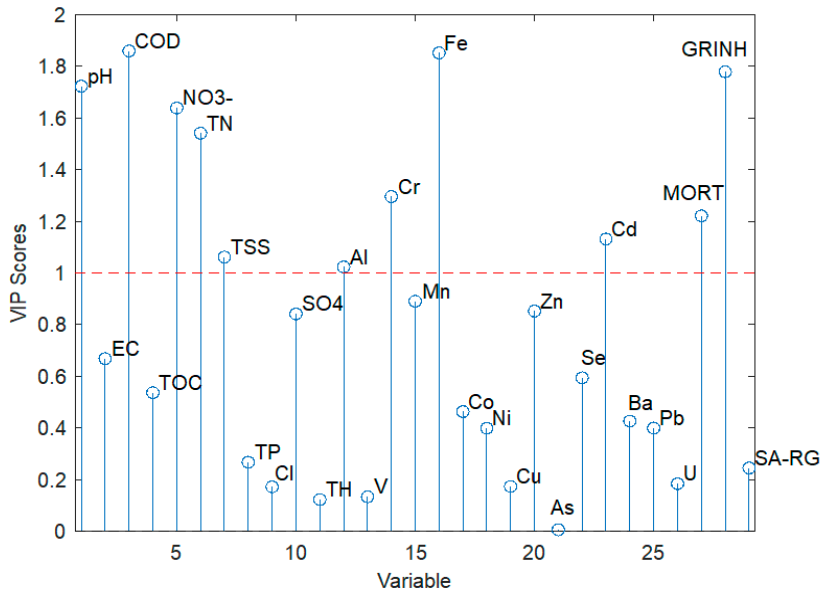

(b)

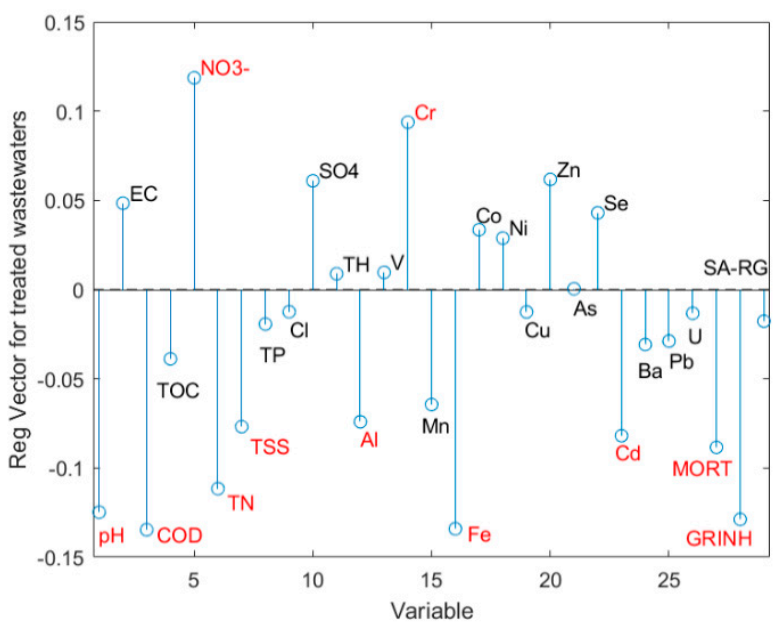

(d)

Figure 6. The partial least squares-discriminant analysis (PLS-DA) model results for untreated wastewaters and treated wastewaters based on physicochemical parameters and ecotoxicological endpoints: (a) Confusion matrix; (b) VIP (variable importance on projection) scores; (c) Regression vector for untreated wastewaters (variables with significant contribution are marked in red); (d) Regression vector for treated wastewaters (variables with significant contribution are marked in red).

The second PLS-DA model was built to discriminate two classes of samples: treated wastewaters (11 samples) and surface waters (22 samples). The confusion matrix and AUC values resemble very good prediction model performance with $97 \%$ and $94 \%$ correct predictions for calibration and cross-validation procedures, respectively (Figure 7a). The misclassified sample is surface water taken after the discharge point of the Plovdiv WWTP. Variables with significant contribution to the classification model are $\mathrm{pH}, \mathrm{EC}$, nitrates, TN, $\mathrm{TP}, \mathrm{Cl}^{-}, \mathrm{Ni}, \mathrm{Cu}, \mathrm{Zn}$, Se and GRINH (Figure $7 \mathrm{~b}$ ). The treated wastewaters are characterized with higher values of all significant variables, excluding $\mathrm{pH}$ and growth inhibition of Heterocypris incongruens (Figure 7c,d). 


\begin{tabular}{|c|c|c|c|}
\hline $\begin{array}{c}\text { Confusion } \\
\text { matrix }\end{array}$ & $\begin{array}{l}\operatorname{AUC}(C)=0.996 ; \\
\operatorname{AUC}(C V)=0.967\end{array}$ & & \\
\hline & & \multicolumn{2}{|c|}{ Actual } \\
\hline & & $\begin{array}{c}\text { Treated } \\
\text { wastewaters }\end{array}$ & $\begin{array}{l}\text { Surface } \\
\text { waters }\end{array}$ \\
\hline \multirow[t]{2}{*}{ Predicted } & $\begin{array}{c}\text { Treated } \\
\text { wastewaters }\end{array}$ & 11 & 1 \\
\hline & Surface waters & 0 & 21 \\
\hline
\end{tabular}

(a)

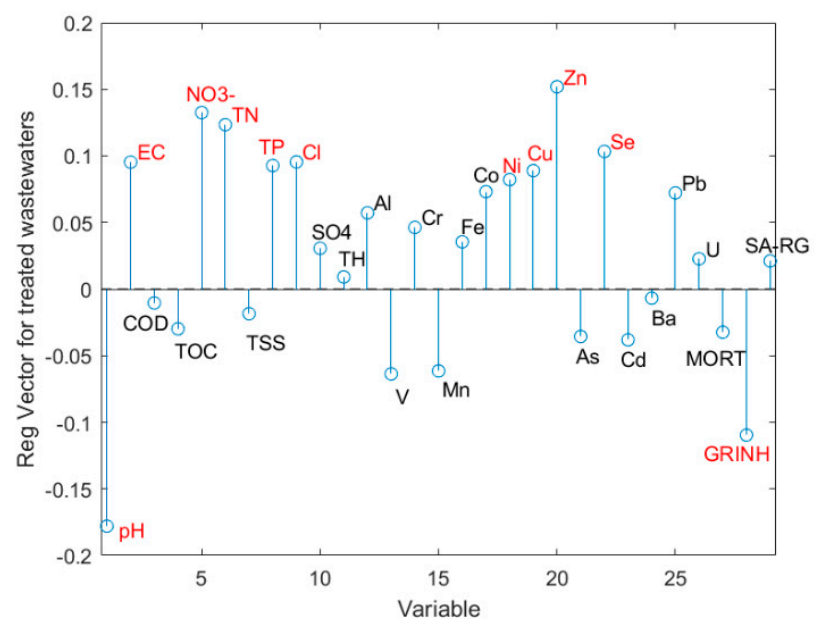

(c)

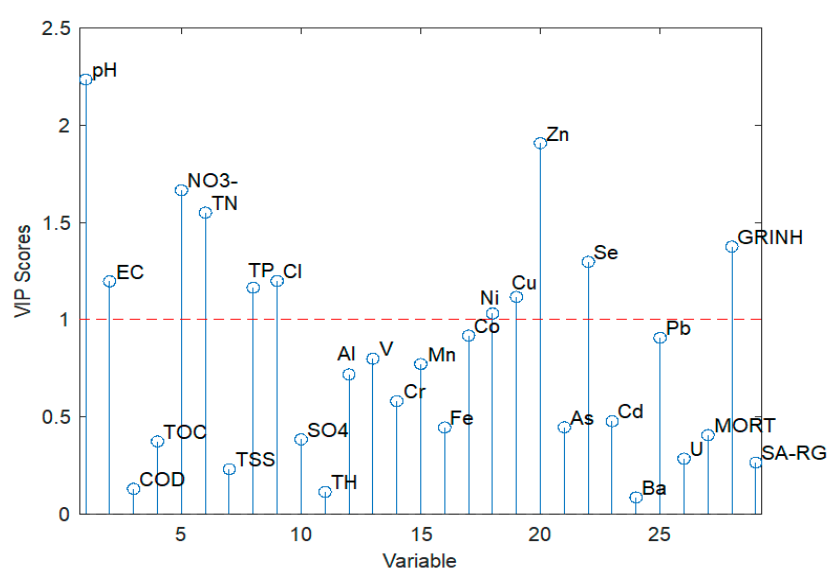

(b)

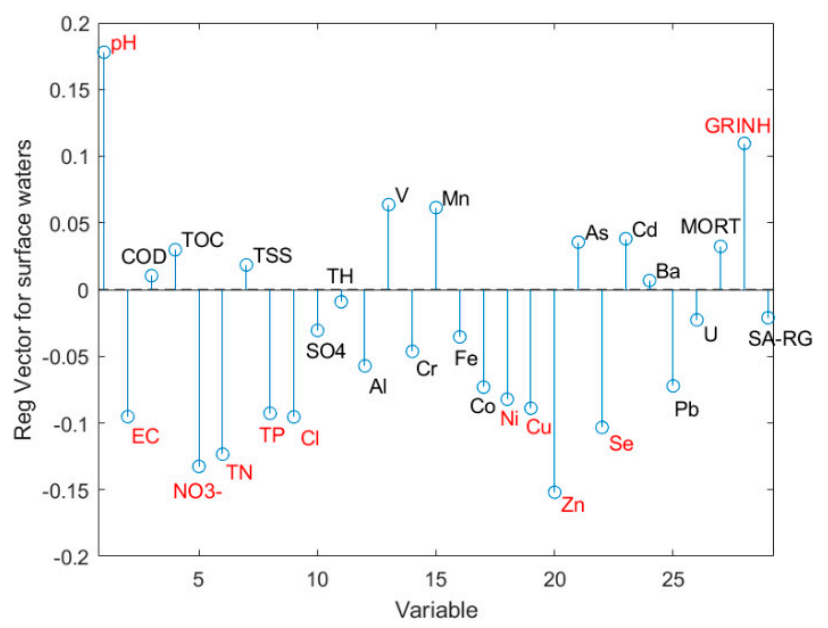

(d)

Figure 7. The partial least squares-discriminant analysis (PLS-DA) model results for treated wastewaters and surface waters based on physicochemical parameters and ecotoxicological endpoints: (a) Confusion matrix; (b) VIP (variable importance on projection) scores; (c) Regression vector for treated wastewaters (variables with significant contribution are marked in red); (d) Regression vector for surface waters (variables with significant contribution are marked in red).

\section{Discussion}

Exceedances of the legal upper limits set in Directive 91/271/EEC have been previously reported for Bulgarian WWTPs $[14,16]$. They detect exceedances in 11- out of 39- studied WWTPs for COD, TN, TP and TSS [16]. Similar to this study, in WWTPs without treatment facilities 3 and 4, elevated concentrations of $\mathrm{N}$ and $\mathrm{P}$ were also found in DUP, PAZ, PDV, PER and POP [14]. In this study, the observed exceedances are only recorded for TP, the WWTPs performance, therefore, is considered very good. The exceeding TP concentrations are due to the lack of phosphorus precipitation step in 5- out of 11- WWTPs studied.

Regarding the chemical elements, ordinance N-4 is applied [41], as it sets requirements for the characterization of the surface waters, establishing maximum allowed concentrations ( $\left.\mathrm{Al}, \mathrm{As}, \mathrm{Cr}, \mathrm{U}_{\text {nat }}\right)$ or annual average concentrations $(\mathrm{Cu}, \mathrm{Fe}, \mathrm{Mn}$ and $\mathrm{Zn})$ as environmental quality standards (EQSs). Since the EQSs for $\mathrm{Cu}$ and $\mathrm{Zn}$ are hardness-based, the lowest maximum allowed concentrations are used as the most conservative estimates. The exceedances for $\mathrm{Zn}$, that are found after the discharges of LOV and PVD indicate that the WWTPs may adversely increase the $\mathrm{Zn}$ concentration in the receiving rivers. 
The observed exceedances of $\mathrm{Cu}$ EQS for the majority of the surface waters (before and after the discharges of the WWTPs) are in line with the exceedances generally found for $\mathrm{Cu}$ in the compliance assessments of the Bulgarian surface waters [42]. The exceedances of As EQS concentrations are generally found in the Ogosta river basin and are a result of historical pollution in the region $[17,43]$.

The PCA results reveal some interesting similarity groups of variables and investigated samples concerning water quality. The factor loading plots (Figure 3) represent different associations of ecotoxicological endpoints with the other variables for 3 out of 4 principal components, which is more pronounced in PC3. The PC2 factor loadings (Figure 3) may be considered as an untreated wastewaters footprint, which predetermines their separation from treated wastewaters and surface water samples (Figure 4). Similarly, PC3 factor loadings determine the separation between treated wastewaters and the other groups (Figure 5). The feature profile of treated wastewaters is characterized by low $\mathrm{pH}$ values and higher $\mathrm{Zn}$ concentrations. The absence of separation between the groups of samples before and after WWTP discharges indicates that no significant changes in investigated physicochemical parameters and ecotoxicological endpoints occur in the receiving surface body.

Two PLS-DA models were performed to reveal the significant variables for the abovementioned separations and also to assess the WWTPs' efficiency and their impact on receiving water bodies.

The PLS-DA classification model discriminating untreated from treated wastewaters (Figure 6) reveals two groups of variables with significant impact. While for the first group of variables, including Heterocypris incongruens response points, higher values for untreated wastewaters are expected (Figure 6c), the higher concentrations of nitrates and $\mathrm{Cr}$ in treated wastewaters need further discussion. The elevated concentrations of nitrates at the outlets of the WWTPs (treated wastewaters), compared to the inlets of the WWTPs (untreated wastewaters) is due to the natural nitrification process in the bio basin, as the nitrate-nitrogen accounts for $4,5 \%$ of the $\mathrm{TN}$ at the inlet and $94 \%$ of the $\mathrm{TN}$ at the outlet. In the influent water, Chromium is usually in the form of $\mathrm{Cr}$ (III), which is mainly adsorbed on the suspended solids, with a small portion in precipitated form [44]. The water chemistry in the bio basin (basic $\mathrm{pH}$, presence of oxygen and $\mathrm{Mn}$ ) is favourable for the oxidation of $\mathrm{Cr}$ (III) to $\mathrm{Cr}$ (VI) [45]. Under these conditions $\mathrm{Cr}$ (VI) is very well soluble, which may explain the concentration increase at the effluents.

All these results show interesting responses of Heterocypris incongruens studies where total parameters (such as COD, TSS, and $\mathrm{pH}$ ) explain observable mortality and growth inhibition, as ostracods are highest located in the trophic level (among studied organisms in this project) and have fully developed gastrointestinal tract where digestion of suspended solids occurs and constitutes an important source of metals and organic pollutants. Moreover, it is also the longest-lasting test (6 days, sub-chronic), making the exposure routes and active feeding behaviour more versatile than any acute and static bioassay (including the plant tests). As confirmed in previous studies [36,46], ostracods are very prone to heavy metals such as $\mathrm{Cd}, \mathrm{Cu}, \mathrm{Cr}, \mathrm{Ni}$ and $\mathrm{Zn}$, which, with $\mathrm{pH}$ variations between different waters studied, explains observable growth inhibition disturbances among samples. As the number of studies with Heterocypris incongruens keeps growing, our efforts to reflect the anthropogenic impact on the environment (in this case surface waters) become more reliable and complete thanks to the possibility of selecting more adequate and versatile batteries of bioassays [47].

The second PLS-DA model results confirm, to a large extent, the proven footprint for the WWTPs' impact on receiving water bodies in a previous study [14] and includes the following parameters: EC, nitrates, $\mathrm{TN}, \mathrm{TP}, \mathrm{Cl}^{-}, \mathrm{Ni}, \mathrm{Cu}, \mathrm{Zn}$ and Se. The important finding here is the lower Heterocypris incongruens growth inhibition values for the class of treated wastewaters. This fact could be explained by the higher $\mathrm{pH}$ of treated wastewaters which leads to a decrease in the bioavailability of some elements such as $\mathrm{Cu}, \mathrm{Ni}$ and $\mathrm{Zn}$ [48-50]. Another reason for decreased GRINH of treated wastewater may be due to the elevated concentrations of nutrients compared to the surface waters, and reduced 
numbers of suspended solids being a significant source of pollutants in untreated waters, as confirmed for Heterocypris incongruens. Again, growth inhibition of Heterocypris incongruens appeared to be the most sensitive parameter (among studied) due to prolonged exposure, in the case of this bioassay, and active food-searching capability.

\section{Conclusions}

Large-scale and on-site WWTPs need constant and critical control systems to assure ecosystems and modern societies are not burdened with wastes generated by societies. For decades, traditional instrumental studies were used for regular monitoring of the efficiency of removing the organic and inorganic pollutants emitted to surface waters [51]; however, it became obvious that instrumental studies alone cannot assure reliable information on the status of water bodies [52]. The new quality of information has been given by adding bioassays [53] and chemometric studies to a range of tools applicable in this important evaluation of WWTP efficiencies. Algal, bacterial and plant tests were the most often used biological tools in such monitoring, however they always seemed to have specific limitations, being of acute character and using, most often, organisms of lower trophic level [54].

In this work, we present collaborative results of advanced studies on assessing the possible burden of Bulgarian surface waters due to the release of treated wastewaters created by citizens of 11 major cities. We observed how versatile and unique information might have been given again by combining instrumental, biological and environmetric solutions into a real-life situation and evaluating the quality of treated and surface waters. We also confirmed that Heterocypris incongruens, despite being test designed for solid sample toxicity assessment, is applicable for the ultra-sensitive evaluation of toxicity levels of liquid samples when respective modifications are introduced and validated for this goal.

Author Contributions: Conceptualization, B.K. and S.T.; methodology, B.K., T.V. and S.T.; software, G.Y., B.K. and S.T.; validation, V.M., G.Y. and B.K.; formal analysis, V.M., G.Y., T.V. and B.K.; investigation, V.M., G.Y., B.K., T.V. and S.T.; resources, S.T. and T.V.; data curation, V.M., G.Y., B.K. and T.V.; writing-original draft preparation, V.M., G.Y., B.K., T.V. and S.T.; writing-review and editing, V.M., G.Y., B.K., T.V. and S.T.; visualization, G.Y. and S.T.; supervision, T.V., B.K. and S.T.; project administration, T.V. and S.T.; funding acquisition, S.T. All authors have read and agreed to the published version of the manuscript.

Funding: This research was funded by the Ministry of Education and Science, Bulgarian National Science Fund, Grant DN 19/15.

Data Availability Statement: The data presented in this study are available on request from the corresponding author.

Acknowledgments: The authors gratefully acknowledge the financial support from the Bulgarian National Science Fund (Grant DN 19/15).

Conflicts of Interest: The authors declare no conflict of interest. The funders had no role in the design of the study; in the collection, analyses, or interpretation of data; in the writing of the manuscript, or in the decision to publish the results.

\section{References}

1. United Nations, Department of Economic and Social Affairs, Population Division. World Urbanization Prospects: The 2014 Revision, Highlights (ST/ESA/SER.A/352); United Nations: New York, NY, USA, 2014.

2. Moghaddam, M.; Mazaheri, M.; Samani, J. Inverse modeling of contaminant transport for pollution source identification in surface and groundwaters: A review. Groundw. Sustain. Develop. 2021, 15, 100651. [CrossRef]

3. European Parliament, Council of the European Union. Directive 2000/60/EC of the European Parliament and of the Council establishing a framework for Community action in the field of water policy. Off. J. Eur. Union 2000, 327, 1-73.

4. Khan, E. Nonpoint source versus point source water pollution. Water Environ. Res. 2020, 92, 1864-1865. [CrossRef] [PubMed]

5. Salim Dantas, M.; Rodrigues Barroso, G.; Corrêa Oliveira, S. Performance of sewage treatment plants and impact of effluent discharge on receiving water quality within an urbanized area. Environ. Monit. Assess. 2021, 193, 289. [CrossRef] [PubMed] 
6. Council of the European Union. Council Directive 91/271/EEC concerning urban waste-water treatment. Off. J. Eur. Union 1991, $135,40-52$.

7. Rule, K.L.; Comber, S.; Ross, D.; Thornton, A.; Makropoulos, C.; Rautiu, R. Diffuse sources of heavy metals entering an urban wastewater catchment. Chemosphere 2006, 63, 64-72. [CrossRef]

8. Buzier, R.; Tusseau-Vuillemin, M.; Keirsbulck, M.; Mouchel, J. Inputs of total and labile trace metals from wastewater treatment plants effluents to the Seine River. Phys. Chem. Earth Parts A/B/C 2011, 36, 500-505. [CrossRef]

9. Chon, H.; Ohandja, D.; Voulvoulis, N. Assessing the Relative Contribution of Wastewater Treatment Plants to Levels of Metals in Receiving Waters for Catchment Management. Water Air Soil Pollut. 2012, 223, 3987-4006. [CrossRef]

10. Gobeil, C.; Rondeau, B.; Beaudin, L. Contribution of municipal effluents to metal fluxes in the St. Lawrence river. Environ. Sci. Tech. 2005, 39, 456-464. [CrossRef]

11. Vink, R.; Behrendt, H.; Salomons, W. Point and diffuse source analysis of heavy metals in the Elbe drainage area: Comparing heavy metal emissions with transported river loads. Hydrobiologia 1999, 410, 307-314. [CrossRef]

12. Venelinov, T.; Yotova, G.; Lazarova, S.; Mihaylova, V.; Tsakovski, S. Impact Assessment of the Wastewater Treatment Plants' Discharges on Maritsa River. Int. J. Bioautomation 2021, 25, 169-182. [CrossRef]

13. Huang, J.; Du, P.; Ao, C.; Ho, M.; Lei, M.; Zhao, D. Multivariate analysis for stormwater quality characteristics identification from different urban surface types in Macau. Bull. Environ. Contam. Toxicol. 2007, 79, 650-654. [CrossRef]

14. Yotova, G.; Lazarova, S.; Kudłak, B.; Zlateva, B.; Mihaylova, V.; Wieczerzak, M.; Venelinov, T.; Tsakovski, S. Assessment of the Bulgarian Wastewater Treatment Plants' Impact on the Receiving Water Bodies. Molecules 2019, 24, 2274. [CrossRef] [PubMed]

15. Marčiulaitienè, E.; Meškauskaite, L.; Pozniak, N.; Sakalauskas, L. Investigation of Filtration Capacity of Surface Wastewater Filters by Mathematical Modelling. Ecol. Chem. Eng. S 2020, 27, 241-255. [CrossRef]

16. Yotova, G.; Venelinov, T.; Tsakovski, S. Chemometric Assessment of Bulgarian Wastewater Treatment Plants' Effluents. Molecules 2020, 25, 4408. [CrossRef]

17. Yotova, G.; Lazarova, S.; Mihaylova, V.; Venelinov, T. Water quality assessment of surface waters and wastewaters by traditional and ecotoxicological indicators in Ogosta River, Bulgaria. Int. J. Bioautomat. 2021, 25, 25-40. [CrossRef]

18. U.S. Environmental Protection Agency. Introduction to Water Quality Based Toxics Control for The Npdes Program; U.S. Environmental Protection Agency: Washington, DC, USA, 1992.

19. Manusadzianas, L.; Balkelyte, L.; Sadauskas, K.; Blinova, I.; Põllumaa, L.; Kahru, A. Ecotoxicological study of Lithuanian and Estonian wastewaters: Selection of the biotests, and correspondence between toxicity and chemical-based indices. Aquat. Toxicol. 2003, 63, 27-41. [CrossRef]

20. Szmigielska, M.; Wróbel, M.; Rybak, J. Assessment of water quality contaminated with arsenic using diatoms and Ostracodtoxkit F test. E3S Web of Conf. 2018, 44, 00174. [CrossRef]

21. Latif, M.; Licek, E. Toxicity assessment of wastewaters, river waters, and sediments in Austria using cost-effective microbiotests Environ. Toxicol. 2004, 19, 302-309. [CrossRef]

22. Kudłak, B.; Wieczerzak, M.; Yotova, G.; Tsakovski, S.; Simeonov, V.; Namiesnik, J. Environmental risk assessment of Polish wastewater treatment plant activity. Chemosphere 2016, 160, 181-188. [CrossRef]

23. Radziemska, M.; Gusiatin, Z.; Cydzik-Kwiatkowska, A.; Cerdà, A.; Pecina, V.; Bęś, A.; Datta, R.; Majewski, G.; Mazur, Z.; Dzięcioł J.; et al. Insight into metal immobilization and microbial community structure in soil from a steel disposal dump phytostabilized with composted, pyrolyzed or gasified wastes. Chemosphere 2021, 272, 129576. [CrossRef] [PubMed]

24. Steliga, T.; Kluk, D. Application of Festuca arundinacea in phytoremediation of soils contaminated with $\mathrm{Pb}, \mathrm{Ni}, \mathrm{Cd}$ and petroleum hydrocarbons. Ecotox. Environ. Saf. 2020, 194, 110409. [CrossRef] [PubMed]

25. Radziemska, M.; Bęś, A.; Gusiatin, Z.M.; Cerdà, A.; Jeznach, J.; Mazur, Z.; Brtnický, M. Assisted phytostabilization of soil from a former military area with mineral amendments. Ecotox. Environ. Saf. 2020, 188, 109934. [CrossRef] [PubMed]

26. Radziemska, M.; Bęś, A.; Gusiatin, Z.M.; Cerdà, A.; Mazur, Z.; Jeznach, J.; Kowal, P.; Brtnický, M. The combined effect of phytostabilization and different amendments on remediation of soils from post-military areas. Sci. Tot. Environ. 2019, 688, 37-45. [CrossRef]

27. García-Lorenzo, M.; Crespo-Feo, E.; Esbrí, J.; Higueras, P.; Grau, P.; Crespo, I.; Sánchez-Donoso, R. Assessment of potentially toxic elements in technosols by tailings derived from $\mathrm{Pb}-\mathrm{Zn}-\mathrm{Ag}$ mining activities at San Quintín (Ciudad real, Spain): Some insights into the importance of integral studies to evaluate metal contamination pollution hazards. Minerals 2019, 9, 346. [CrossRef]

28. Kluk, D.; Steliga, T. Potential of helianthus annuus for phytoremediation of lead, zinc, total petroleum hydrocarbons (TPH) and polycyclic aromatic hydrocarbons (PAHs) contaminated soil. Naft-Gaz 2019, 7, 379-387. [CrossRef]

29. Wróbel, M.; Stojanowska, A.; Nosarzewska, M.; Rutkowski, R.; Rybak, J. The impact of chemical contaminants on biocenosis (ecotoxycological studies). E3S Web Conf. 2019, 100, 00088. [CrossRef]

30. Tarnawski, M.; Baran, A. Use of Chemical Indicators and Bioassays in Bottom Sediment Ecological Risk Assessment. Arch. Environ. Contam. Toxicol. 2018, 74, 395-407. [CrossRef]

31. Singh, P.; Nel, A.; Durand, J. The use of bioassays to assess the toxicity of sediment in an acid mine drainage impacted river in gauteng (South Africa). Water SA 2017, 43, 673-683. [CrossRef]

32. Mierzwa-Hersztek, M.; Gondek, K.; Klimkowicz-Pawlas, A.; Baran, A.; Bajda, T. Sewage sludge biochars managementEcotoxicity, mobility of heavy metals, and soil microbial biomass. Environ. Toxicol. Chem. 2018, 37, 1197-1207. [CrossRef] 
33. Oleszczuk, P. The toxicity of composts from sewage sludges evaluated by the direct contact tests phytotoxkit and ostracodtoxkit. Waste Manag. 2008, 28, 1645-1653. [CrossRef] [PubMed]

34. Lyubomirova, V.; Mihaylova, V.; Djingova, R. Determination of macroelements in potable waters with cell-based inductivelycoupled plasma mass spectrometry. Spectrosc. Eur. 2020, 32, 18-21.

35. Lyubomirova, V.; Djingova, R. Determination of Se in Bulgarian commercial flour and bread. Comp. Rend. L'Académ. Bul. Sci. 2015, 68, 847-852.

36. Kudłak, B.; Wolska, L.; Namieśnik, J. Determination of EC 50 toxicity data of selected heavy metals toward Heterocypris incongruens and their comparison to "direct-contact" and microbiotests. Environ. Monit. Assess. 2011, 174, 509-516. [CrossRef]

37. Wieczerzak, M.; Kudłak, B.; Namieśnik, J. Impact of Selected Drugs and Their Binary Mixtures on the Germination of Sorghum bicolor (Sorgo) Seeds. Env. Sci. Pol. Res. 2018, 25, 18717-18727. [CrossRef]

38. Schneider, C.A.; Rasband, W.S.; Eliceiri, K.W. NIH Image to ImageJ: 25 years of image analysis. Nat. Methods 2012, 9, 671-675 [CrossRef] [PubMed]

39. Platikanov, S.; Rodriguez-Mozaz, S.; Huerta, B.; Barceló, D.; Cros, J.; Batle, M.; Poch, G.; Tauler, R. Chemometrics quality assessment of wastewater treatment plant effluents using physicochemical parameters and UV absorption measurements. $J$. Environ. Manag. 2014, 140, 33-44. [CrossRef] [PubMed]

40. Navarro, A.; Tauler, R.; Lacorte, S.; Barceló, D. Occurrence and transport of pesticides and alkylphenols in water samples along the Ebro River Basin. J. Hydrol. 2010, 383, 18-29. [CrossRef]

41. Ordinance N-4/2012 for Characterisation of Surface Waters. $D V$ 2013, 22, 9-46. (In Bulgarian). Available online: http: / / eea.government.bg/bg/legislation/water/Naredba13.pdf (accessed on 15 December 2021).

42. Venelinov, T.; Tsakovski, S. How to Implement User-Friendly BLMs in the Absence of DOC Monitoring Data: A Case Study on Bulgarian Surface Waters. Water 2022, 14, 246. [CrossRef]

43. Zhelezov, G.; Benderev, A. State of pollution of Ogosta River waters. Rev. Bul. Geol. Soc. 2021, 82, 195-197. [CrossRef]

44. Stasinakis, A.; Thomaidis, N. Fate and Biotransformation of Metal and Metalloid Species in Biological Wastewater Treatment Processes. Crit. Rev. Environ. Sci. Technol. 2010, 40, 307-364. [CrossRef]

45. Angelova, I.; Ivanov, I.; Venelinov, T. Study of hexavalent chromium origin in the groundwater of northern Bulgaria. SGEM Conf. Proc. 2018, 18, 853-860. [CrossRef]

46. Kudłak, B.; Wieczerzak, M.; Namieśnik, J. Determination of Toxicological Parameters of Selected Bioactive Organic Chemicals Using the Ostracodtoxkit F. Chem.-Didac.-Ecol.-Metrol. 2018, 23, 113-126. [CrossRef]

47. Sonavane, M.; Schollée, J.; Hidasi, A.; Creusot, N.; Brion, F.; Suter, M.; Hollender, J.; Aït-Aïssa, S. An integrative approach combining passive sampling, bioassays, and effect-directed analysis to assess the impact of wastewater effluent. Environ. Toxicol. Chem. 2018, 37, 2079-2088. [CrossRef]

48. De Schamphelaere, K.; Janssen, C. Development and field validation of a biotic ligand model predicting chronic copper toxicity to Daphnia magna. Environ. Toxicol. Chem. 2004, 23, 1365-1375. [CrossRef]

49. Deleebeeck, N.; De Schamphelaere, K.; Janssen, C. A novel method for predicting chronic nickel bioavailability and toxicity to Daphnia magna in artificial and natural waters. Environ. Toxicol. Chem. 2008, 27, 2097-2107. [CrossRef]

50. Heijerick, D.; De Schamphelaere, K.; Van Sprang, P.; Janssen, C. Development of a chronic zinc biotic ligand model for Daphnia magna. Ecotoxicol. Env. Saf. 2005, 62, 1-10. [CrossRef]

51. Olkowska, E.; Kudłak, K.; Tsakovski, S.; Ruman, M.; Simeonov, V.; Polkowska, Z. Assessment of the water quality of Kłodnica River catchment using self-organizing maps. Sci. Total Environ. 2014, 476, 477-484. [CrossRef]

52. Stalter, D.; Magdeburg, A.; Oehlmann, J. Comparative toxicity assessment of ozone and activated carbon treated sewage effluents using an in vivo test battery. Water Res. 2010, 44, 2610-2620. [CrossRef]

53. Tchounwou, P.; Wilson, B.; Ishaque, A.; Schneider, J. Toxicity tests to assess pollutants removal during wastewater treatment and the quality of receiving waters in Argentina. Environ. Toxicol. 2001, 16, 217-224. [CrossRef]

54. Papa, M.; Paredes, L.; Feretti, D.; Viola, G.; Mazzoleni, G.; Steimberg, N.; Pedrazzani, R.; Lema, J.; Omil, F.; Carballa, M. How should ecohazard of micropollutants in wastewater be gauged? Using bioassays to profile alternative tertiary treatments. Environ. Eng. Res. 2021, 26, 200153. [CrossRef] 